\title{
Hypertrophy of NADH-diaphorase positive myenteric neurons in rat jejunum after acute infection caused by Toxoplasma gondii
}

\author{
Pereira LS (1), da Silva AV (2), Araújo EJA (2), Sant'Ana DMG (2)
}

(1) Undergraduate Program in Pharmacy, Paranaense University, UNIPAR, Umuarama, Paraná State, Brazil; (2) Graduate Program in Animal Science, Paranaense University, UNIPAR, Umuarama, Paraná State, Brazil.

ABSTRACT: Toxoplasmosis, a globally distributed feline-associated zoonosis caused by the protozoan Toxoplasma gondii, affects birds and mammals, including humans. This study assesses the consequences of acute $T$. gondii infection for $\mathrm{NADH}$-diaphorase positive myenteric neurons in rat jejunum. Ten male Wistar rats (Rattus norvegicus) were divided into two groups: $\mathrm{G} 1(n=5)$ and $\mathrm{G} 2(\mathrm{n}=5)$. Animals from G2 were orally inoculated with 500 genotype III (M7741) $T$. gondii oocysts. Twenty-four hours after inoculation, the animals were euthanized and had their jejuna removed, through laparotomy, and measured (length and width) to calculate their areas. Intestinal segments were submitted to NADH-diaphorase histochemistry to evidence the most metabolically active subpopulation of myenteric neurons. No changes were found in body weight; intestinal length, width or area; or neuron population density. Increase of body cell area and cytoplasm and decrease of nuclear area of the myenteric neurons of infected animals were observed by morphometric analysis.

KEY WORDS: Toxoplasma gondii, jejunum, myenteric plexus.

CONFLICTS OF INTEREST: There is no conflict.

\section{CORRESPONDENCE TO:}

DÉBORA DE MELLO GONÇALES SANT'ANA, Laboratório de Neurogastroenterologia Experimental, Universidade Paranaense, UNIPAR, Praça Mascarenhas de Moraes, 4290, Umuarama, PR, 87502-210, Brasil. Phone: +44 3621 2849. Email: debora@unipar.br. 


\section{INTRODUCTION}

Toxoplasma gondii is an apicomplexan coccidian protozoan that may be found parasitizing a number of cells, mostly parenchymatous cells, leukocytes and cells from the mononuclear phagocytic system, besides muscle and neuronal cells $(1,2)$. There are three infectious stages of T. gondii: tachyzoites, bradyzoites and sporozoites (3). Sporozoites are found in sporocysts within sporulated oocysts that are eliminated by felines - the definitive hosts (4). Sporulation, necessary for the oocysts to become infectious, occurs in the environment usually within five days, but perhaps longer according to temperature and oxygen availability (4). After that, oocysts in the environment may contaminate the water and food, which once consumed become the means of parasite transmission. When ingested, the oocyst has to resist the digestive enzymes and the gastric juice in order to establish itself inside the host. For this reason, the oocyst is highly infectious as its wall presents a multilayer structure extremely resistant to both physical and chemical injuries (5).

T. gondii infection is a universally propagated zoonosis, found mainly in birds and mammals including human beings, in which it presents high prevalence levels (4). However, there is low incidence of the clinical disease, toxoplasmosis, among humans (6). On the other hand, fetuses, congenitally infected newly-born infants and the immunocompromised may develop severe forms of toxoplasmosis (7).

The central nervous system (CNS) is considered an immune-privileged site in relation to $T$. gondii infection as it presents restricted access to the inflammatory cells; however, the parasite may be found within neurons and glial cells such as the astrocytes (8). Because of this affinity between $T$. gondii and these nerve cells, it is believed that gastrointestinal neurons may also change due to infection. Moreover, the lack of a hematoencephalic barrier and the absence of microglial cells in the enteric nervous system (ENS) ganglions may result in augmented vulnerability of its neurons to the infection. In toxoplasmic infections, the occurrence of diarrhea in rabbits and lesions and necrosis in C57BL/6 mouse ileum may suggest that the ENS is also susceptible to the protozoan $(9,10)$. Thus, specific studies to assess the effects of $T$. gondii on ENS neurons are extremely important since these cells control motility, secretion and absorption, essential functions for the host's well-being (11) Therefore, this study analyzes the effects of the infection on the myenteric neuron population through an acute infection caused by T. gondii oocysts in rats. 


\section{MATERIALS AND METHODS}

All of the experimental procedures were previously approved by the Ethics Committee on Animal Experimentation (CEPEEA) of the Paranaense University (protocol n. 12361/2008).

Ten 90-day-old adult male rats weighing $306.3 \pm 21.83 \mathrm{~g}$ (Rattus norvegicus) were employed. They were randomly assigned into two groups, G1 and G2, composed of five animals each. Animals from G1 received saline solution orally, whereas G2 specimens were inoculated with 500 genotype III (M7741) T. gondii oocysts. After 24 hours - a period considered sufficient to cause an acute infection - all rats were intramuscularly anesthetized with acepromazine $2 \%(1.26 \mathrm{~mL} / \mathrm{kg})$, ketamine $10 \%$ $(1.26 \mathrm{~mL} / \mathrm{kg})$, xylazine chloridate $2.5 \%(0.42 \mathrm{~mL} / \mathrm{kg})$ and atropine sulfate $1 \%(0.22$ $\mathrm{mL} / \mathrm{kg}$ ) (12). After anesthesia, the animals were euthanized by intracardiac injection of potassium chlorate $(\mathrm{KCl})$. Finally, through midline laparotomy, the intestinal segments were removed and the jejunum was separated and measured.

The segments of all animals were submitted to NADH-diaphorase histochemistry to evidence metabolic-active myenteric neurons (13). The jejunum was washed and filled with Krebs solution, immersed in a $0.3 \%$ Triton $X-100 \circledR$ solution (Sigma, USA) for five minutes and then washed again in Krebs solution. Segments were submersed in a medium containing $0.05 \mathrm{~g}$ of $\beta-\mathrm{NADH}$ (Sigma, USA) and $25 \mathrm{~mL}$ of nitro blue tetrazolium $(0.5 \mathrm{mg} / \mathrm{mL})$ (Sigma, USA) for 45 minutes. The reaction was interrupted with buffered formol. Then, the segments were fixed in $10 \%$ buffered formol solution until the microdissection procedure in which the mucosa and submucosa were removed with the aid of a transillumination stereomicroscope to expose the myenteric plexus located in the external muscle. Thus, the whole mounts were dissected in ascending series of ethyl alcohol, diaphanized in xylol and mounted using Permount $®$ (Fisher Scientific, USA).

The whole mounts were assigned into three regions: mesenteric $\left(0^{\circ}-60^{\circ}\right.$ and $300^{\circ}$ $\left.360^{\circ}\right)$, intermediary $\left(60^{\circ}-120^{\circ}\right.$ and $\left.240^{\circ}-300^{\circ}\right)$ or antimesenteric $\left(120^{\circ}-240^{\circ}\right)$, considering $0^{\circ}$ as the mesentery insertion angle. Based on this division, the morphoquantitative analysis of the myenteric plexus neurons was conducted. The neurons within 40 microscopic fields from each region, in the intestinal segment of each animal, totaling an area of $16.8 \mathrm{~mm}^{2}$, were counted by using a Motic BL® optical microscope (Motic, Canada) at 40x magnification. 
The areas of the body cell and the nucleus of 100 neurons, per region, per animal, in each group were measured in the morphometric analysis with the aid of a 40x optical microscope and Motic Images Plus 2.0® software (Motic, Canada). The cytoplasm area was calculated from the difference between these areas. Moreover, the ratio between the areas of the nucleus and the body cell was determined in order to verify the proportion occupied by that organelle within the body cell.

The Shapiro-Wilk test was used in order to assess the data distribution type with respect to body weight; the length, width and area of the jejunum; neuron count, and division into classes. The D'Agostino Pearson test was employed for measuring the neurons. Data that presented normal distribution were compared by using Student's t-test for independent samples, whereas non-normally distributed data were compared with the Mann-Whitney test. $\mathrm{P}<0.05$ constituted significant differences in all analyzed cases.

\section{RESULTS}

The infected animals presented no changes with respect to the body weight or the length, width or area of the jejunum during the infection period studied (Table 1).

Macroscopic analysis presented no apparent lesions in the intestines of any animals. Quantitative analysis of positive NADH-diaphorase myenteric neurons indicated no significant changes $(p=0.8027)$ in the number of neurons, which was $279.30 \pm 63.18$ neurons $/ \mathrm{mm}^{2}$ in $\mathrm{G} 1$ and $268.91 \pm 64.08$ neurons $/ \mathrm{mm}^{2}$ in the inoculated group (G2). The morphometric analysis found significant differences in all the measurements conducted, including the nucleus/body-cell ratio. Furthermore, increases in the area of the body cell and cytoplasm and decrease of the nuclear area were noted and, consequently, a decrease in the proportion occupied by the nucleus within the body cell (Figure 1; Table 2). The correlations among the measured areas are presented in Table 3.

Figures 2 and 3 display the distribution of NADH-diaphorase-positive neurons in the jejunum, according to body cell area (Figure 2) and nucleus/body cell ratio (Figure 3), demonstrating significant change in only one class of body cell area (Figure 2). 
Table 1. Mean and standard deviation of body weight, length and width; median and percentiles (P25; P75) of jejunum area in healthy rats (G1) and those submitted to infection with a genotype III Toxoplasma gondii strain (G2) for 24 hours ( $p>0.05$ )

\begin{tabular}{c|c|c|c|c}
\hline Group & Body weight $(\mathbf{g})$ & Length $(\mathbf{c m})$ & Width $(\mathbf{c m})$ & Jejunum area $\left(\mathbf{c m}^{2}\right)$ \\
\hline $\mathrm{G} 1(\mathrm{n}=5)$ & $305.4 \pm 21.84$ & $109.8 \pm 9.04$ & $1.0 \pm 0.12$ & $104.0(92.7 ; 117.0)$ \\
\hline $\mathrm{G} 2(\mathrm{n}=5)$ & $294.8 \pm 20.37$ & $109.2 \pm 5.45$ & $1.4 \pm 0.51$ & $121.0(110.0 ; 214.0)$ \\
\hline
\end{tabular}

Table 2. Median and percentiles (P25; P75) of areas of the body cell, nucleus and cytoplasm, and the nucleus/body cell ratio of $\mathrm{NADH}$-diaphorase-positive neurons from jejunum of healthy rats (G1) and those submitted to infection with a genotype III Toxoplasma gondii (G2) strain for 24 hours

\begin{tabular}{|c|c|c|c|c|}
\hline Group & $\begin{array}{l}\text { Body cell area } \\
\left(\mu \mathrm{m}^{2}\right)\end{array}$ & $\begin{array}{c}\text { Nucleus area } \\
\left(\mu \mathrm{m}^{2}\right)\end{array}$ & $\begin{array}{c}\text { Cytoplasm area } \\
\left(\mu \mathrm{m}^{2}\right)\end{array}$ & $\begin{array}{l}\text { Nucleus/body } \\
\text { cell ratio }\end{array}$ \\
\hline $\mathrm{G} 1(\mathrm{n}=5)$ & $\begin{array}{c}165.49(131.12 \\
203.42)^{\star}\end{array}$ & $\begin{array}{c}55.31(42.81 \\
69.17)^{\star}\end{array}$ & $\begin{array}{c}108.26(83.90 \\
139.67)^{\star}\end{array}$ & $\begin{array}{l}0.33(0.28 \\
0.39)^{*}\end{array}$ \\
\hline $\mathrm{G} 2(\mathrm{n}=5)$ & $\begin{array}{c}170.24(129.60 ; \\
221.68)^{*}\end{array}$ & $\begin{array}{c}53.30(39.90 \\
67.74)^{*}\end{array}$ & $\begin{array}{c}116.99(85.87 \\
157.35)^{*}\end{array}$ & $\begin{array}{l}0.30(0.26 \\
0.36)^{*}\end{array}$ \\
\hline
\end{tabular}

Values with asterisk in the same column present statistically significant difference $(p<0.05)$. 


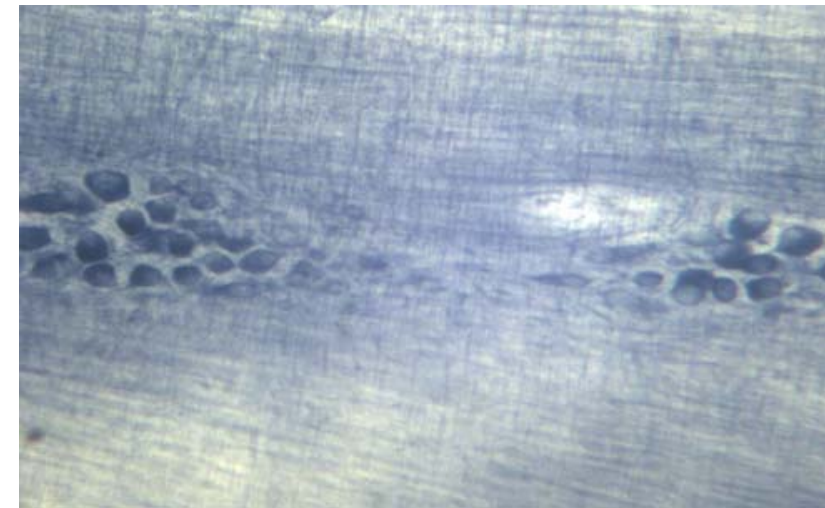

A

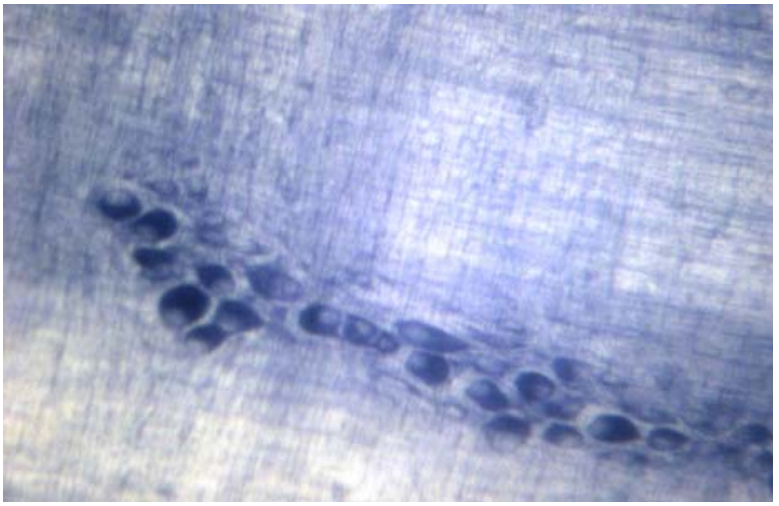

B

Figure 1. (A) Myenteric ganglion of jejunum from a healthy rat (G1) and (B) a rat infected with a genotype III Toxoplasma gondii strain (G2) for 24 hours.

Table 3. Intergroup correlations for body cell, nuclear and cytoplasmic areas of rat jejunum neurons from healthy rats (G1) and those infected by a genotype III Toxoplasma gondii strain $(\mathrm{G} 2)$ for 24 hours

\begin{tabular}{c|c|c|c}
\hline Group & $\begin{array}{c}\text { Body cell area } \mathbf{x} \\
\text { nuclear area }\end{array}$ & $\begin{array}{c}\text { Body cell area } \mathbf{x} \\
\text { cytoplasmic area }\end{array}$ & $\begin{array}{c}\text { Nuclear area } \mathbf{x} \\
\text { cytoplasmic area }\end{array}$ \\
\hline $\mathrm{G} 1(\mathrm{n}=5)$ & 0.73 & 0.94 & 0.48 \\
\hline $\mathrm{G} 2(\mathrm{n}=5)$ & 0.78 & 0.96 & 0.60 \\
\hline
\end{tabular}

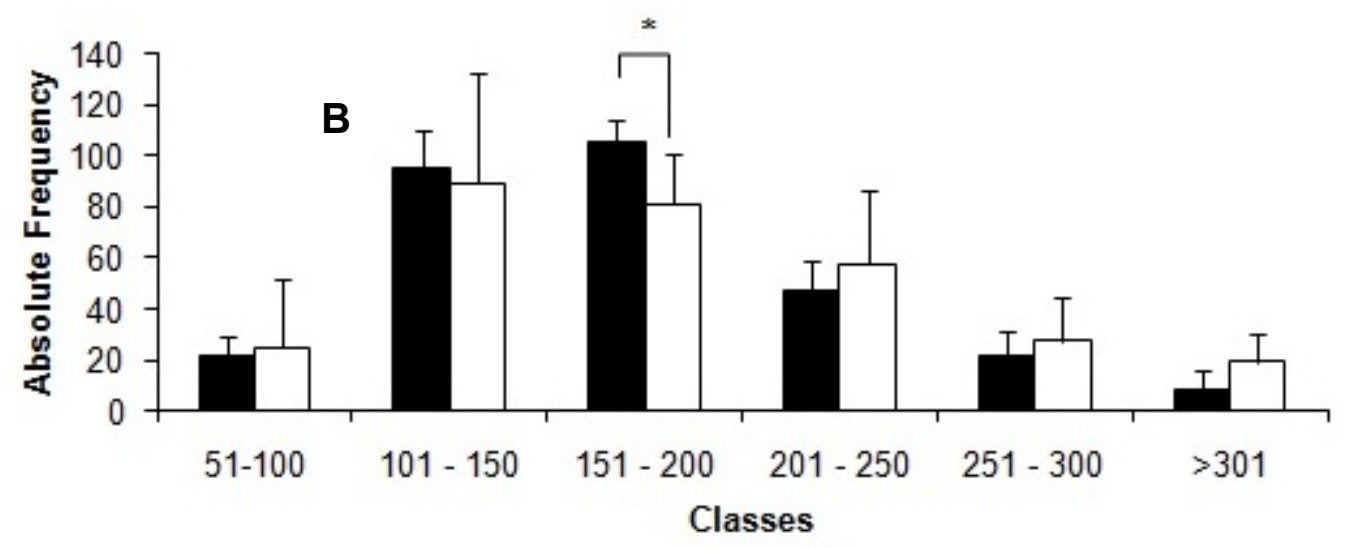

-GROUP 1 aGROUP 2

Figure 2. Histogram of the body area of jejunum myenteric neurons from healthy rats (G1) and those infected with a genotype III Toxoplasma gondii strain (G2). Marked columns from the same class differ significantly $(p<0.05)$. 


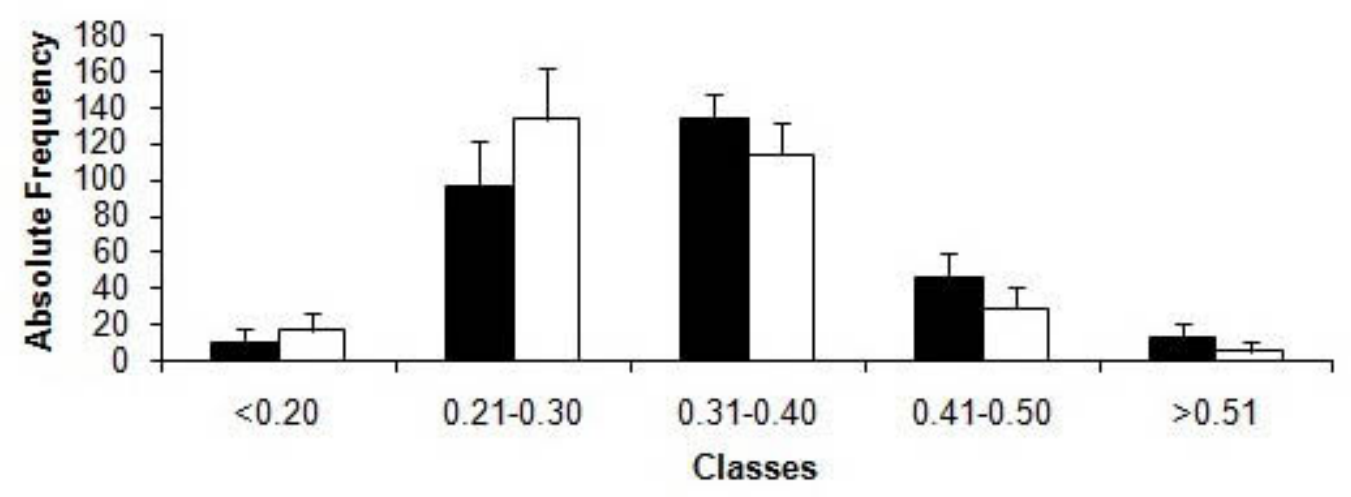

-GROUP 1 aGROUP 2

Figure 3. Histogram of the nuclear/body cell area ratio of jejunum myenteric neurons from healthy rats (G1) and those infected with a genotype III Toxoplasma gondii strain $(G 2)$.

\section{DISCUSSION}

Toxoplasma gondii is known for its ability to invade a number of nucleated cells, thus spreading throughout the host's organism. In immunocompentent individuals, the parasite may be present in several tissues under the form of tissue cysts formed due to immunological defense factors that had previously induced the conversion from tachyzoites to bradyzoites (14). These cysts are found in different organs such as the brain, intestine and muscles (2).

In this study, no macroscopic changes were found in the studied organ. However, it has already been demonstrated that several animal species present changes on the intestine wall when orally infected with $T$. gondii (15). This shows that the gastrointestinal tract may be compromised by toxoplasmic infection, which may reach the ENS as well. Such instances of tissue damage are probably associated with an exaggerated immune response, which occasionally causes necrosis in the organ. During this study, neither diarrhea nor any manifestation characterizing the infection was noted in any of the animals. Nevertheless, in another study, diarrhea was noticed in infected rabbits and recognized as one of the ordinary clinical signals of toxoplasmosis (9).

Animals' resistance against the parasite varies considerably. Seven days after infection, mice develop severe small intestinal necrosis and succumb to infection (15). Rats are considered to be one of the experimental hosts most resistant to Toxoplasma gondii infection; however, the scarcity of such works conducted on rats 
hinders comparisons (16). The virulence of the strain is also a factor influencing clinical signals and infectious manifestations.

In vitro studies suggest that the virulence of the strain compromises the stimulus to the immune response, tissue penetration and the encystment capacity (17). Genotype I strains are considered highly virulent in laboratory animals (18). Furthermore, isolated genotype III strains in the Northern hemisphere have been presenting low virulence which enables the development of chronic infection with the formation of tissue cysts in mice $(19,20)$. The strain used in this study - M7741 was isolated in the USA in 1958 from an ovine diaphragm sample that was thought to have low virulence (21). On the other hand, the virulence of genotype III Brazilian strains found in South America has differed from those of the northern hemisphere (22). The period of infection in this study might have been insufficient to provoke signals and symptoms peculiar to toxoplasmosis - thus suggesting a subclinical infection.

This was an exploratory research as it is one of the first studies on any continent to assess the interaction between the ENS and T. gondii. Therefore, different types of strains have been studied via inoculation and duration of infection in order to further understand this interaction (23-25).

The amount of neurons did not change, indicating the absence of neuronal loss. Similarly, other authors did not find alterations in the amount of neurons in rat descending colon chronically infected with genotypes I and III Brazilian strains (23, 24). In another study on genotype II Brazilian strains, no neuronal loss in rat ileum with acute infection was observed (25). In the present study, the analyzed neurons belong to a more metabolically active subpopulation (positive NADH-diaphorase) which was predictive of the expected finding that the decrease in the amount of neurons affected by $T$. gondii is dependent on the metabolism of the host cell to sustain and divide itself $(26,27)$. Myenteric neuronal changes may occur independently of its death since the interaction between enteric neurons and $T$. gondii may be direct or indirect. Indeed, neuronal death could be caused by infection, although the parasite needs cells to survive. On the other hand, the fact that the number of neurons was sustained suggests that, probably, no direct parasitism occurred in the cells.

The neuronal changes observed such as the augmentations of the body cell and cytoplasm and the decrease of the nucleus may have resulted from the parasitic 
infection by either direct or indirect action. However, the only class of neurons affected was perikarion neurons between 151 and $200 \mu^{2}$. Enlarged body cell, nuclear and cytoplasmic areas in the ileum myenteric neurons were observed in rats acutely infected with the genotype II T. gondii strain (25). Utilizing the genotype III strain, another study found decreases in those areas in the rat descending colon during acute infection (24). However, elevations of the body cell and cytoplasmic areas in myenteric neurons in the descending colon of chronically infected rats were observed in a study involving the genotype I strain (23).

The results obtained in the current study may be justified not only by the parasitic infection of the neurons but also, more likely, by the action of the immune system in response to the parasitic inoculation. When the infectious occurs orally, the barrier found by the parasite is the intestinal epithelium constituted by the enterocytes. The protozoan invades the enterocytes in order to break through this physiological barrier and initiate the infection. In response to the invasion, the enterocytes release cytotoxic molecules such as nitric oxide (NO) in addition to chemokines and cytokines, which attract polymorphonuclear leukocytes, macrophages and dendritic cells (28). Nitric oxide is a cytotoxic molecule that acts by inhibiting essential mitochondrial and nuclear enzymes (29).

In the CNS, nervous cells also participate in the immunological response while the $T$. gondii infection induces the production of a variety of cytokines by microglias, astrocytes and neurons, which, in turn, promote or suppress the inflammatory response (8). The recruiting of defense cells and the release of cytokines and proinflammatory substances also affecting the host cell occur during immunological responses, despite targeting the elimination of the parasite. Given that T. gondii may be a mandatory intracellular parasite, the immunological measures performed by the immune system may destroy the host cells in order to eliminate the parasite.

Organs and cells of the immune system are spread throughout the organism, including in the gastrointestinal tract, where the lymphoid tissue is associated with the mucosa (30). This is due to the importance of the intestine as the entry point for infectious microorganisms. In the small intestine, the lymphoid tissue presents Peyer's patches that form dome-like structures all the way to the intestinal lumen where lymphocytes and dendritic cells are located (31). Thus, the response accelerates as the defense cells are specifically located. These cells will act first, in the event of the infection, and then release cytokines in order to stimulate and 
regulate the immune response that may occur (28). However, these cytokines may change the genic expression and cell metabolism. Therefore, the fact that this may have occurred in the neurons analyzed in this study justifies the alterations found.

Correlation results suggest that the hypertrophy of metabolic active neurons is related to the augmentation of the cytoplasm. Such changes in the cellular biology of neurons will possibly influence their physiology in order to sustain the intestinal homeostasis. It is not known why the cytoplasm of these neurons increased, though this may have occurred as a result of the increase in cytosol and/or organelles. In order to elucidate what truly caused such a cytoplasmic increase, an analysis by transmission electronic microscopy would be indicated.

\section{CONCLUSION}

Acute infection caused by a genotype III Toxoplasma gondii strain was unable to cause quantitative alterations of jejunum positive NADH-diaphorase neurons or changes either in the body weight or the width, length or area of infected rat jejunum. On the other hand, neuronal plasticity changes involving the augmentation of cytoplasmic and body cell areas, diminishment of the nuclear area as well as the decrease of the nucleus/body cell area ratio were noted.

\section{REFERENCES}

1. Miller CM, Boulter NR, Ikin RJ, Smith NC. The immunobiology of the innate response to Toxoplasma gondii. Int J Parasitol. 2009;39(1):23-9.

2. Weiss LM, Kim K. The development and biology of bradyzoites of Toxoplasma gondii. Front Biosci. 2000;5(1):D391-405.

3. Tenter AM. Toxoplasma gondii in animals used for human consumption. Mem Inst Oswaldo Cruz. 2009;104(2):364-9.

4. Dubey JP, Lindsay DS, Speer CA. Structures of Toxoplasma gondii tachyzoites, bradyzoites, and sporozoites and biology and development of tissue cysts. Clin Microbiol Rev. 1998;11(2):267-99.

5. Mai K, Sharman PA, Walker RA, Katrib M, Sousa D, McConville MJ, et al. Oocyst wall formation and composition in coccidian parasites. Mem Inst Oswaldo Cruz. 2009;104(2):281-9. 
6. Dubey JP, Graham DH, da Silva DS, Lehmann T, Bahia-Oliveira LM. Toxoplasma gondii isolates of free-ranging chickens from Rio de Janeiro, Brazil: Mouse mortality, genotype, and oocyst shedding by cats. J Parasitol. 2003;89(4):851-3.

7. Black MW, Boothroyd JC. Lytic cycle of Toxoplasma gondii. Microbiol Mol Biol Rev. 2000;64(3):607-23.

8. Carruthers VB, Suzuki Y. Effects of Toxoplasma gondii infection on the brain. Schizophr Bull. 2007;33(3):745-51.

9. Mitsuka R, Beckner da Silva AC, Navarro IT, Breganó JW, Vidotto O.Toxoplasma gondii: I. Avaliação da virulência de oito amostras. Braz J Vet Res Anim Sci. 1998; 35(1):29-31.

10. Rachinel N, Buzoni-Gatel D, Dutta C, Mennechet FJ, Luangsay S, Minns LA, et al. The induction of acute ileitis by a single microbial antigen of Toxoplasma gondii. $\mathrm{J}$ Immunol. 2004;173(4):2725-35.

11. Costa M, Brookes SJH, Hennig GW. Anatomy and physiology of the enteric nervous system. Gut. 2000;47(Suppl 4):15-9.

12. Pachaly JR, Sant'Ana DMG, Araujo EJA, Ciffoni EMG, Acco O. Anesthesia of Wistar rats (Rattus novergicus) with allometrically scaled doses of ketamine, xylazine, acepromazine and atropine - preliminary report. Arq Cienc Vet Zool. 2003;6(1):195.

13. Gabella G. Detection of nerve cells by a histochemical technique. Experientia. 1969; 25(2):218-9.

14. Laliberté J, Carruthers VB. Host cell manipulation by the human pathogen Toxoplasma gondii. Cell Mol Life Sci. 2008;65(12):1900-15.

15. Schreiner $M$, Liesenfeld $O$. Small intestinal inflammation following oral infection with Toxoplasma gondii does not occur exclusively in C57BL/6 mice: review of 70 reports from the literature. Mem Inst Oswaldo Cruz. 2009;104(2):221-33.

16. Dubey JP, Shen SK, Kwok OC, Frenkel JK. Infection and immunity with the RH strain of Toxoplasma gondii in rats and mice. J Parasitol. 1999;85(4):657-62.

17. Gilbert RE, Freeman K, Lago EG, Bahia-Oliveira LMG, Tan HK, Wallon M, et al. Ocular sequelae of congenital toxoplasmosis in Brazil compared with Europe. PLoS Negl Trop Dis 2008;2(8):277.

18. Sevá AP, Da Silva RC, Da Silva AV, De Castro APB, Menozzi BD, Langoni H. Avaliação da virulência de cepas de Toxoplasma gondii, em camundongos, isolados de cães com sinais neurológicos, em Botucatu, SP. Vet e Zootec. 2006;13(1):33-43. 
19. Howe DK, Sibley LD. Toxoplasma gondii comprises three clonal lineages: correlation of parasite genotype with human disease. J Infect Dis. 1995;172(6):15616.

20. Dubey JP. Strategies to reduce transmission of Toxoplasma gondii to animals and humans. Vet Parasitol. 1996;64(1-2):65-70.

21. Jacobs L, Remington JS, Melton ML. A survey of meat samples from swine, cattle, and sheep for the presence of encysted Toxoplasma. J Parasitol. 1960;46(1):23-8.

22. Dubey JP, Navarro IT, Graham DH, Dahl E, Freire RL, Prudencio LB, et al. Characterization of Toxoplasma gondii isolates from free range chickens from Paraná, Brazil. Vet Parasitol. 2003;117(3):229-34.

23. Soares J, Moreira NM, Da Silva AV, Sant'Ana DMG, Araújo EJA. Infecção crônica por Toxoplasma gondii induzindo hipertrofia de neurônios do plexo mientérico do cólon descendente de Rattus norvegicus. Rev Bras Parasitol Vet. 2009;18(2):57-60.

24. Sugauara EYY, Sant'Anna DMG, Almeida EC, Reis AB, Silva AV, Araújo EJA. Alterations of the myenteric plexus of the ileum and the descending colon caused by Toxoplasma gondii (genotype III). Arq Neuropsiquiatr. 2008;66(3):516-23.

25. Sugauara EYY, Sant'Ana DMG, Da Silva AV, Souza EA, Araújo EJA. Hypertrophy of the neurons in the ileum of rats infected with cysts of Toxoplasma gondii (genotype II). Acta Sci Biol Sci. 2009;31(2):195-201.

26. Pereira MA, Bagatin MC, Zanoni JN. Effects of the ascorbic acid supplementation on NADH-diaphorase myenteric neurons in the duodenum of diabetic rats. Biocell. 2006;30(2):295-300.

27. Coppens I, Joiner KA. Parasite/host cell interactions in toxoplasmosis: new avenues for intervention? Expert Rev Mol Med. 2001;2001(1):1-20.

28. Buzoni-Gatel D, Werts C. Toxoplasma gondii and subversion of the immune system. Trends Parasitol. 2006;22(10):448-52. 
Pereira LS et al. Hypertrophy of NADH-diaphorase positive myenteric neurons in rat jejunum after acute infection caused by Toxoplasma gondii. J Venom Anim Toxins incl Trop Dis. 2010;16(2):310

29. Brunet LR. Nitric oxide in parasitic infections. Int Immunopharmacol. 2001; 1(8):1457-67.

30. Kasper LH, Courret N, Darche S, Luangsay S, Mennechet F, Minns L, et al. Toxoplasma gondii and mucosal immunity. Int J Parasitol. 2004;34(3):401-9.

31. Kasper LH, Buzoni-Gatel D. Ups and downs of mucosal cellular immunity against protozoan parasites. Infect Immun. 2001;69(1):1-8. 